\title{
An update on the distribution of Glossina (tsetse flies) at the wildlife-human-livestock interface of Akagera National Park, Rwanda
}

Richard S. Gashururu ( $\nabla$ gasirich@yahoo.fr)

University of Rwanda - Nyagatare Campus https://orcid.org/0000-0001-9625-8708

Samuel M. Githigia

University of Nairobi College of Agriculture and Veterinary Sciences

Methode N Gasana

Rwanda Agricultura and Animal Resources Development Board

Richard Habimana

University of Rwanda - Nyagatare Campus

Ndichu Maingi

University of Nairobi College of Agriculture and Veterinary Sciences

Giuliano Cecchi

FAO: Food and Agriculture Organization of the United Nations

Massimo Paone

FAO: Food and Agriculture Organization of the United Nations

Weining Zhao

FAO: Food and Agriculture Organization of the United Nations

Daniel K. Masiga

ICIPE: International Centre for Insect Physiology and Ecology

James Gashumba

Rwanda polytechnic

\section{Research}

Keywords: Glossina, distribution, Trypanosomosis, wildlife-human-livestock interface, Akagera NP, Rwanda

Posted Date: January 13th, 2021

DOl: https://doi.org/10.21203/rs.3.rs-143646/v1

License: (a) (i) This work is licensed under a Creative Commons Attribution 4.0 International License. Read Full License 
Version of Record: A version of this preprint was published at Parasites \& Vectors on June 2nd, 2021. See the published version at https://doi.org/10.1186/s13071-021-04786-3. 


\section{Abstract}

\section{Background}

Glossina (Tsetse flies) biologically transmit trypanosomes that infect both humans and animals. Knowledge of their distribution patterns is a key element to better understand the transmission dynamics of trypanosomosis. Tsetse distribution in Rwanda has not been well enough documented and little is known of their current distribution. This study determined the current spatial distribution, abundance, diversity, and seasonal variations of tsetse flies in and around the Akagera National Park.

\section{Methods}

A longitudinal stratified sampling, following the seasons was used. Biconical traps were deployed in 55 sites for six consecutive days of each study month from May 2018 to June 2019, and emptied every 48hours. Flies were identified using FAO keys and the number of flies per trap day (FTD) was used to determine the apparent density. Pearson chi-square $(\mathrm{X} 2)$ and parametrical tests (t-test and ANOVA) were used to determine the variations between the variables. The significance $(p<0.05)$ at $95 \%$ confidence interval was considered. Logistic regression was used to determine the association between tsetse occurrence and the associated predictors.

\section{Results}

39,516 tsetse flies were collected, of which $73.4 \%$ and $26.6 \%$ were from inside Akagera NP and the interface area respectively. Female flies accounted for $61.3 \%$ while $38.7 \%$ were males. Two species were identified, i.e. G. pallidipes [ $\mathrm{n}=29,121,7.4$ flies/trap/day (FTD)] and G. morsitans centralis $(\mathrm{n}=10,395 ; 2.6$ FTD). The statistical difference in numbers was significant between the two species $(p=0.000)$. The flies were more abundant during the wet season (15.8 FTD) than the dry season (4.2 FTD). Large numbers of flies were trapped around the swamp areas (69.1 FTD) inside the park and in Nyagatare District (11.2 FTD) at the interface. Glossina morsitans was 0.218 times less likely to occur outside the park. The chance of co-existing between the two species reduced outside the protected area (0.021 times).

\section{Conclusions}

The occurrence of Glossina seems to be limited to the protected Akagera NP and a narrow band in its surroundings. This finding will be crucial to design appropriate control strategies. Glossina pallidipes was found in higher numbers and therefore conceivably the most important vector of trypanosomosis. Regional coordinated control and regular monitoring of Glossina distribution are recommended.

\section{Background}

Glossina (tsetse flies) are biological vectors of trypanosomes, which cause trypanosomiasis in both humans and animals through blood-feeding [1]; [2]; [3]; [4] . The distribution patterns of tsetse species in 
an area is a key element to better understand the transmission dynamics of trypanosomosis [5]; [6]. This information is a requirement for strategic, risk-based control of the vectors and the disease [7]; [8].

The presence and abundance of Glossina are associated with the environment [9]. The habitat, land use, and ecological settings are determinants of tsetse fly distribution and therefore the disease transmission [10]; [11]. On top of this, the availability of hosts and their distribution in an area determine the dispersal of tsetse flies, especially the savannah group [9].

Environmental changes play a role in changing disease transmission [12]. Habitat fragmentation and human activities reduce considerably the distribution and abundance of savannah species, leading them to be confined to protected areas where they find a conducive environment and hosts to feed on [13];[14]; [15]. However, this situation results in an increased challenge of tsetse bites on livestock and humans around the protected infested area [12].

Information on Glossina distribution and trypanosomes in Rwanda was much documented during the colonial period [16]; [17]; [18]; [19]; [20]. However, little has been done to update this information since independence [21].

Three species of tsetse flies, i.e. G. pallidipes (Subgenus Glossina (morsitans) group - Austen 1903), G. morsitans centralis (Subgenus Glossina (morsitans) group - Machado 1970), and G. brevipalpis (Subgenus Austenina (Fusca) group - Newstead 1910) were reported in the lowland eastern savannah region of Rwanda [20]; [22]; [23]. The fourth species G.fuscipes martinii (Subgenus Nemorhina (palpalis) group - Zumpt, 1935) was once reported in the south-west region of Rwanda bordering Burundi [24]. However, the species has not been reported again since then [25]. The Kagera area is comprised of the former Mutara region and the affiliated protected areas including Akagera NP. Population growth has overtime reduced the suitable habitats for Glossina due to land acquisition [26]. The de-gazettement of roughly two-thirds of the protected land comprising the entire Mutara hunting area $\left(300 \mathrm{~km}^{2}\right)$ and part of Akagera National Park for resettlements and farming activities after the year 1997 greatly reduced the protected areas [27]; [28]. This reduced the Akagera NP to about 1,120 square kilometres out of the 2500 $\mathrm{km}^{2}$ initially gazetted [29]; [28].

Akagera NP is adjacent to other game reserves in Tanzania, (Ibanda Game Reserve in the north and Kimisi Game Reserve in the south) (Figure 1). Akagera NP is a known home to tsetse flies, and its surroundings are not spared by tsetse challenge and the transmission of trypanosomosis. The park has suitable habitats for tsetse survival and hosts a high concentration of preferred wild animals such as warthogs and buffaloes on which the flies constantly feed. [30]. Along the park boundary, many cattle farms surround its entire length together with the settled farmers ' homesteads [31]. This situation makes the area a suitable habitat and therefore increases the tsetse challenge at the interface. The strategic control of diseases that may originate from wildlife or which are shared between livestock, wildlife and humans at the interface is crucial in the area [32]. 
This study determined the current spatial distribution, abundance, diversity, and seasonal variations of Glossina species in the region. This information is crucial in order to design evidence-based strategies for the control of the vector and Tsetse-transmitted trypanosomosis [7],[33], and it particularly contributes valuable entomological data to validate the elimination of Human African Trypanosomosis (HAT) [34].

\section{Methods}

\section{Study area}

The study was carried out in the eastern province of Rwanda, where Glossina are still reported in lowlands characterized by a depressed relief. The province shares borders with Tanzania in the East and Uganda in the North (Figure 1).

The study focused on Akagera NP and its surroundings, and it extended over three neighboring districts (i.e. Kayonza, Gatsibo, and Nyagatare), with altitudes ranging between $1200 \mathrm{~m}$ and $1700 \mathrm{~m}$. The interface area outside the Akagera NP is dominated almost entirely by cattle farms. The rains follow a bimodal pattern with an average rainfall of about $1000 \mathrm{~mm}$ per annum, even though it is less regular compared to other regions of the country, leading to frequent dry spells. At the interface, the vegetation cover consists of grassland, woodland, and often bushland closer to the park especially for localities in which the study was conducted. The temperature varies between $19^{\circ} \mathrm{C}$ to $29^{\circ} \mathrm{C}$. The long dry season spans the months of June, July up to August while the long wet season comprises the month of March, April, and May [35].

Established as a national park in 1934, the park draws its name from the Akagera River that runs along the international border with the United Republic of Tanzania [30]. Akagera NP is the only protected savannah region in Rwanda and therefore the only shelter for savannah-adapted species of tsetse. Akagera NP has a sub arid savannah habitat, subdivided into three ecosystems: Swamp (wetland and wetland fringes), mountain, and savannah. There are different vegetation types within the above ecosystems mainly grasslands, bushed grasslands, wooded grasslands, woodland (mainly Acacia), dry and humid forests [36]; [30]. The wetlands are permanently flooded areas with marshlands and a complex system of lakes fed by the Akagera River. The wetlands make $30 \%$ of the park surface and the terrestrial part making the remaining $70 \%$. The altitude is characteristic of the eastern region; however, it has a mountainous north to south-central ridge along the western boundary that can reach nearly $1750 \mathrm{~m}$ [37].

\section{Entomological survey}

A longitudinal stratified sampling was carried out from May 2018 to June 2019 to determine seasonal variations in tsetse fly populations as described by Leak and Vreysen [38]. Inside the park, ecosystems were used for the stratification of sampling, whereas the districts were used at the interface area outside the park. In each of three park ecosystems (i.e. swamps, savannah and mountain), locations were randomly selected, nonetheless the most suitable sites for tsetse were purposefully chosen. At the 
interface, in addition to stratification using the districts, the same approach was used to select the sites. The information on the potential Glossina-habitat suitability such as near human residence, the density, and distribution of cattle population, communal watering points, grazing areas, overnight cattle collection, and the farmers' knowledge on the existence of flies was taken into account. Fifty five (55) sites (12 inside the park and 43 along the interface) were therefore selected for the study. To determine the effect of the distance to the park at the interface, sites located less than $3 \mathrm{~km}$ from the park border were considered as close, while those located more than $3 \mathrm{~km}$ were considered as distant.

Biconical traps [39] supplied by Vestergaard Frandsen (Lausanne, Switzerland), were used in the study. These traps are widely used and are efficient in sampling and population monitoring [40]. Traps were deployed for six consecutive days of each month (3months in the rainy season and 3 months in the dry season) and emptied every 48 hours [41]. Two traps were deployed in the same site at a distance of $200 \mathrm{~m}[6]$, and the fly catches of the two traps were later combined to represent a site. The number of traps deployed in area was determined by its size [42]. The trap effectiveness was improved by using a 3 weeks-old cow urine and acetone as baits, kept in plastic bottles with an opening dispensing the odour. Grease was applied at the bottom of trap support to prevent ants from climbing to the trap. Each trapping site was georeferenced by a global positioning system device (Garmin Ltd, Kansas, USA) to generate a map later.

Flies were morphologically identified using a stereomicroscope (Opta Tech SK392, Poland) as described in the FAO training manuals [43]; [38]; . For each site, records of number, species, sex, and other biting flies were taken. Flies with damaged or lost body parts were excluded from the identification and are not part of the results.

\section{Analysis}

The analysis was performed by SPSS software (SPSS Inc., IL, USA). The average number of flies caught per trap per day (FTD) referred to as the apparent density (AD), was obtained after dividing the total number of flies caught in a trap by the number of days the trap has been in place. The term 'abundance' refers to the apparent density to express the average number of flies available in a specific site [6]. Pearson chi-square $(\chi 2)$ was used to determine the variations between the variables such as the area, season, district, species, sex and localities. The P-value of less than 0.05 , significant at $95 \%$ of confidence interval were taken into account. Parametrical tests (t-test and ANOVA) were used to compare whether the average number of flies caught per trap per day differs between factors / predictors such as area, season, ecosystem, month, district and locality. Logistic regression was used to determine the association between the occurrence of tsetse flies and the associated predictors (cited above and explained in the design), followed by the determination of odds ratios (OR) for each predictor.

\section{Results}

A total of 39,516 tsetse flies was collected, of which 29,019 (73.4\%) and 10,497 (26.6\%) were from Akagera NP and the interface area, respectively (Figure 2). The difference in the occurrence of tsetse flies 
between the two areas was statistically significant $(\mathrm{p}=0.000)$.Two species of Glossina, G. pallidipes ( $n=29,121 ; 7.4$ overall FTD) and $G$. morsitans centralis ( $n=10.395 ; 2.6$ overall FTD) were identified, of which the females accounted for $61.3 \%(n=24,225)$, while $38.7 \%(n=15,291)$ were males (Table 1$)$. The difference in occurrence of the two species was statistically significant $(p=0.000)$. The flies were more abundant during the wet season ( $n=31,295 ; 15.8$ FTD) compared to the dry season $(n=8,221 ; 4.2$ FTD). Figure 3 and 4 show the seasonal distribution in densities and species with details of the respective months.

Inside the park, the fly distribution differed between ecosystems, where a higher fly catch was recorded from the swamps area $(n=19,904 ; 69.1$ FTD) compared to the mountains $(n=7,304 ; 25.4$ FTD) and the savannah ( $n=1,811 ; 6.3$ FTD). The difference in fly catch between ecosystems was statistically significant $(p=0.000)$. Variations in fly catch were observed outside the park, within the three districts surrounding the park. Tsetse catch was $n=8,053$ (11.2 FTD); $n=2,266$ (1.2 FTD); $n=178$ (0.4 FTD) respectively for Nyagatare, Kayonza and Gatsibo (Figure 5). The difference in catch was statistically significant $p=0.000$ when Kayonza and Gatsibo were compared to Nyagatare, but not significant between Gatsibo and Kayonza ( $p=0.107)$. The occurrence of Glossina at the interface area drops rapidly in a distance of few kilometres from the park boundary (Figure 6). The probability of co-existence between $G$. pallidipes and G. morsitans centralis reduced outside Akagera NP (Table 2).

High catches were mainly found inside the park and a narrow band of Nyagatare District. High tsetse densities are associated with swampy vegetation

The area of the circles is directly proportional to the apparent density.

Table 1: Distribution of Glossina by species and sex across study areas and seasons

\begin{tabular}{|c|c|c|c|c|c|c|c|c|c|}
\hline \multirow[t]{2}{*}{ Variable } & \multicolumn{3}{|c|}{$\begin{array}{l}\text { Glossina morsitans } \\
\text { centralis }\end{array}$} & \multicolumn{3}{|c|}{ Glossina pallidipes } & \multirow[t]{2}{*}{$\begin{array}{l}\text { Grand } \\
\text { total }\end{array}$} & \multirow[t]{2}{*}{$\begin{array}{l}\text { Overall } \\
\text { FTD }\end{array}$} & \multirow[t]{2}{*}{$\begin{array}{l}p \\
\text { value }\end{array}$} \\
\hline & $M$ & $F$ & $\Sigma$ & M & $\mathbf{F}$ & $\Sigma$ & & & \\
\hline $\begin{array}{l}\text { Dry } \\
\text { season }\end{array}$ & 786 & 1380 & 2166 & 2288 & 3767 & 6055 & 8221 & 4.2 & \\
\hline $\begin{array}{l}\text { Wet } \\
\text { season }\end{array}$ & 3250 & 4979 & 8229 & 8967 & 14099 & 23066 & 31295 & 15.8 & $\begin{array}{l}<.000 \\
0.000\end{array}$ \\
\hline Interface & 894 & 1485 & 2379 & 3114 & 5004 & 8118 & 10497 & 3.4 & \\
\hline $\begin{array}{l}\text { Akagera } \\
\text { NP }\end{array}$ & 3142 & 4874 & 8016 & 8141 & 12862 & 21003 & 29019 & 33.6 & $<.000$ \\
\hline
\end{tabular}
$\mathrm{M}=$ Male
$\mathrm{F}=$ Female
$\Sigma=$ Total
FTD = Flies/Trap/Day 
Glossina were more abundant in Akagera NP than it was at the interface and the wet season was associated with high fly catches compared to the dry season. Note the variation in sex composition across seasons and study areas. The female flies were more abundant than the males.

The difference is highly significant in April $(\mathrm{p}=0.00,95 \% \mathrm{Cl})$ compared to other months. $G m c=$ Glossina morsitans centralis; $G p=$ Glossina pallidipes; $\mathrm{FTD}=$ Fly per Trap per Day

Districts are strata at the interface (A, B) and ecosystems of Akagera NP (C, D). Gmc $=$ Glossina morsitans centralis; $\mathrm{Gp}=$ Glossina pallidipes; $\mathrm{FTD}=$ Fly per Trap per Day.

Negative distance values signpost the sites inside Akagera park, whereas positive values show the sites at the interface area. The further tsetse fly was captured in $7 \mathrm{Km}$ from the park boundary during the wet season.

Maximum likelihood analysis for the existence and co-existence of G. pallidipes and G. morsitans centralis

Table 2: Multivariate logistic regression analysis for occurrence and co-occurrence of tsetse species 


\begin{tabular}{|c|c|c|c|c|c|c|c|c|c|}
\hline \multirow[t]{2}{*}{ Predictor } & \multicolumn{3}{|c|}{ G. pallidipes } & \multicolumn{3}{|c|}{ G. morsitans } & \multicolumn{3}{|c|}{ Coexistence } \\
\hline & $\begin{array}{l}\text { Fly } \\
\text { catch }\end{array}$ & $\begin{array}{l}\text { OR } \\
\text { (95\% } \\
\text { Cl) }\end{array}$ & $\mathbf{P}$ & $\begin{array}{l}\text { Fly } \\
\text { catch }\end{array}$ & $\begin{array}{l}\text { OR } \\
\text { (95\% } \\
\text { Cl) }\end{array}$ & $\mathbf{P}$ & $\begin{array}{l}\text { Fly } \\
\text { catch }\end{array}$ & $\begin{array}{l}\text { OR }(95 \% \\
\mathrm{Cl})\end{array}$ & $\mathbf{P}$ \\
\hline \multicolumn{10}{|l|}{ Area } \\
\hline $\begin{array}{l}\text { Akagera } \\
\text { N.P. }\end{array}$ & 21003 & 1.00 & & 8016 & 1.00 & & 29019 & 1.00 & \\
\hline Interface & 8118 & $\begin{array}{l}1.275 \\
(1.216- \\
1.336)\end{array}$ & 0.000 & 2379 & $\begin{array}{l}0.218 \\
(0.113- \\
0.423)\end{array}$ & 0.000 & 10497 & $\begin{array}{l}0.021 \\
(0.007- \\
0.065)\end{array}$ & 0.000 \\
\hline \multicolumn{10}{|l|}{ Season } \\
\hline Dry & 6055 & $\begin{array}{l}0.899 \\
(0.858- \\
0.942)\end{array}$ & 0.000 & 2166 & $\begin{array}{l}1.412 \\
(1.263- \\
1.578)\end{array}$ & 0.000 & 8221 & $\begin{array}{l}2.860 \\
(1.781- \\
4.593)\end{array}$ & 0.000 \\
\hline Wet & 23066 & 1.00 & & 8229 & 1.00 & & 31295 & 1.00 & \\
\hline \multicolumn{10}{|l|}{ Month } \\
\hline March & 4275 & $\begin{array}{l}1.416 \\
(1.264- \\
1.586)\end{array}$ & 0.000 & 1399 & $\begin{array}{l}0.648 \\
(0.469- \\
0.897)\end{array}$ & 0.009 & 5674 & $\begin{array}{l}0.312 \\
(0.163- \\
0.596)\end{array}$ & 0.000 \\
\hline April & 13903 & $\begin{array}{l}1.512 \\
(1.365- \\
1.675)\end{array}$ & 0.000 & 4589 & $\begin{array}{l}0.547 \\
(0.432- \\
0.691)\end{array}$ & 0.000 & 18492 & $\begin{array}{l}0.002 \\
(0.001- \\
0.004)\end{array}$ & 0.000 \\
\hline May & 4888 & $\begin{array}{l}1.093 \\
(0.980- \\
1.219)\end{array}$ & 0.111 & 2241 & $\begin{array}{l}0.670 \\
(0.515- \\
0.872)\end{array}$ & 0.003 & 7129 & $\begin{array}{l}0.023 \\
(0.011- \\
0.48)\end{array}$ & 0.000 \\
\hline June & 2763 & $\begin{array}{l}1.628 \\
(1.437- \\
1.843)\end{array}$ & 0.000 & 812 & $\begin{array}{l}0.507 \\
(0.375- \\
0.685)\end{array}$ & 0.000 & 3575 & $\begin{array}{l}0.073 \\
(0.034- \\
0.153)\end{array}$ & 0.000 \\
\hline July & 1955 & $\begin{array}{l}1.283 \\
(1.128- \\
1.459)\end{array}$ & 0.000 & 733 & $\begin{array}{l}0.664 \\
(0.486- \\
0.907)\end{array}$ & 0.010 & 2688 & $\begin{array}{l}0.070 \\
(0.27- \\
0.180)\end{array}$ & 0.000 \\
\hline August & 1337 & 1.00 & & 621 & 1.00 & & 1958 & 1.00 & \\
\hline Ecosystem & & & & & & & & & \\
\hline Mountain & 5097 & $\begin{array}{l}0.823 \\
(0.775- \\
0.873)\end{array}$ & 0.000 & 2207 & $\begin{array}{l}1.215 \\
(1.145- \\
1.289)\end{array}$ & 0.000 & 7304 & $\begin{array}{l}1.000 \\
\left(0.00-.^{b}\right)\end{array}$ & 1.000 \\
\hline
\end{tabular}




\begin{tabular}{|c|c|c|c|c|c|c|c|c|c|}
\hline Savannah & 1231 & $\begin{array}{l}0.756 \\
(0.582- \\
0.839)\end{array}$ & 0.000 & 580 & $\begin{array}{l}1.322 \\
(1.192- \\
1.467)\end{array}$ & 0.000 & 1811 & ND & ND \\
\hline Swampy & 14675 & 1.00 & & 5229 & 1.00 & & 19904 & 1.00 & \\
\hline \multicolumn{10}{|l|}{ District } \\
\hline Kayonza & 1663 & $\begin{array}{l}2.335 \\
(1.447- \\
3.769)\end{array}$ & 0.001 & 603 & $\begin{array}{l}0.428 \\
(0.265- \\
0.691)\end{array}$ & 0.001 & 2266 & $\begin{array}{l}99.360 \\
(63.481- \\
155.517)\end{array}$ & 0.000 \\
\hline Gatsibo & 159 & $\begin{array}{l}0.770 \\
(0.691- \\
0.857)\end{array}$ & 0.000 & 19 & $\begin{array}{l}1.299 \\
(1.167- \\
1.446)\end{array}$ & 0.000 & 178 & $\begin{array}{l}13.090 \\
(9.096- \\
18.836)\end{array}$ & 0.000 \\
\hline Nyagatare & 6296 & 1.00 & & 1757 & 1.00 & & 8053 & 1.00 & \\
\hline
\end{tabular}

$\mathrm{OR}=$ Odds Ratio; $\mathrm{Cl}=$ Confidence Interval, $\mathrm{P}=\mathrm{P}$ value; $\mathrm{ND}=$ Not Determined; Reference categories: Akagera NP for area, Wet for seasons, August for months, Swampy for ecosystems, Nyagatare for districts and Yes for co-existence

The chance of co-existing between the two species reduced outside the protected area (0.021 times). The probability to get $G$. morsitans centralis was 1.412 times more in the dry season than G. pallidipes $(0.899$ times). The coexistence of both species reduced 2.860 times more in the dry season than it was during the wet season. With reference to August, G. pallidipes was more collected in June (1.628 times), April (1.512 times), and March (1.416 times).

Inside the park, G. pallidipes occurred less in the mountain ( 0.823 times less) and savannah ecosystems (0.756 times less) than it was in swampy. However, G. morsitans centralis increased 1.215 times more in mountains and 1.322 times more in savannah. The co-existence of both species was the same in mountains and swamps. With reference to Nyagatare District, G. pallidipes occurred 2.335 times more in Kayonza and 0.770 times less in Gatsibo. The occurrence of G. morsitans centralis was 0.428 times less in Kayonza and 1.299 times more in Gatsibo. The co-existence of both species reduced 13.090 times in Gatsibo and enormously in Kayonza (99.360 times) compared the situation in Nyagatare.

\section{Discussion}

This study shows an important shrink in tsetse distribution outside the current park as opposed to the old distribution maps [20]; [24]; [21]. One of the major reasons for this is that the majority of the previously reported infested area and half of Akagera Park was rezoned for human settlement and farming activities [27]; [28]. This has led to changes in land use, habitat break-up, and increased human activities which in turn reduce tsetse distribution in an area, especially for species of the savannah group [10]; [14].

This situation has been the norm for many areas in sub-Saharan Africa, where the edges of protected areas are experiencing demographic pressure [44]. A similar reduction in G. morsitans populations was reported in eastern and southern Africa, including Zambia [13]; [45] and Malawi [46]. The lack of suitable 
habitats across the interface could explain such decline around Akagera NP [14]. This pattern is also apparent in western Africa, where tsetse flies of the morsitans group are increasingly found only in remnant populations, mostly associated with protected areas [47]; [15].

In a survey conducted in 2012 in Tanzania, the game reserves of Ibanda and Kimisi were found to be infested with Glossina morsitans and characterized as high-risk tsetse infested areas. The same survey characterized an area neighbouring Kimisi, a game controlled area as a Non-Tsetse infested area, possibly due to lower concentration of wild animals, the source of blood meals for tsetse flies [48]. All three areas are at the border with Rwanda and adjacent to Akagera NP. The linkage between the protected areas in Tanzania and Akagera NP in terms of tsetse infestation is a reminder of the transboundary nature of the trypanosomosis problem.

This study clearly shows that the Akagera NP remains a favourable refuge for tsetse populations in the area, and therefore contributing to the constant risk of trypanosomosis transmission in the neighbourhood. Tsetse habitat in the eastern region of Rwanda has reduced greatly due to the demographic pressure. The remaining savannah habitat seems to favour $G$. pallidipes, which tends to dominate other savannah species in the region (Ciosi, Masiga, and Turner 2014; Saarman et al. 2019); [52]. The high tsetse abundance in Akagera NP was found all year round with seasonal variations from wet to dry season. The abundance is much associated with Acacia swampy ecosystem as demonstrated in Tanzania by Ngonyoka [6].

The tsetse challenge to livestock and humans remains at the interface with the park where the community of farmers are settled and cattle are reared in big numbers. Van den Bossche [12] described a similar scenario and the same was found around Serengeti National Park in Tanzania [14]. The distance to the Akagera NP boundary, type of vegetation, and land use seemed to be the factors determining the abundance of tsetse flies at the interface area as it was confirmed by Salekwa [53]. Among the three strata used at the interface, large numbers of Glossina were observed in Nyagatare District. The latter district is located in the north of the park where there is a high concentration of wild animals [30] and high densities of livestock, which contributes to making the area a more suitable tsetse habitat.

The higher abundance of tsetse flies during the rainy season is explained by their behavioural activities. Tsetse flies customarily aggregate in dense vegetation in the dry season and disperse remarkably into areas that are more open during the rainy season [54]; [38]. This behaviour affects the fly catches [41], one of the reasons why traps deployed during the sunny period (June, July and August) caught fewer flies than those deployed in wet season (March, April and May) according to the local climatic conditions. Nevertheless, the combined effects of hosts, vegetation, climate and human settlements affect the abundance and distribution of flies.

This study only found two species G. pallidipes and G. morsitans centralis among the three previously reported species. Their distribution is fairly homogenous for both species across all the vegetation types. G. pallidipes was numerically dominant in all surveyed localities. It had densities three times higher than G. morsitans centralis, but this was not reflected by a broader distribution. Most traps that captured zero 
G. morsitans centralis also did not get any G. pallidipes. There was a relatively higher population of $G$. morsitans centralis in this study compared to earlier findings of Mihok [21]. G.pallidipes were $82.6 \%$ whereas G. morsitans centralis were $15.2 \%$. However, the later work was area-limited and did not include Akagera NP, so comparisons may be misleading. In particular, the difference could be linked to the adjacent Tanzanian side, which was reported to be infested with G. morsitans [48], though the traps in these areas did not catch any of these during this study.

The abundance of G. pallidipes goes in line with the situation in several other countries in the eastern and southern Africa regions [52]; [48]; [55]. This species is the most widely distributed tsetse species in those regions, hence the main vector of AAT and potentially the vector of sleeping sickness [56]. However, recent studies highlight the genetic modifications amid Glossina populations [57] due to environmental changes [58];[59];[60] which could lead to the dominance and adaptations of certain species in a region. This needs to be assessed in the Akagera region as well to locate isolated tsetse populations. This knowledge could help to assess the risk of reinvasion and inform about the feasibility and desirability of eliminating tsetse-transmitted trypanosomes [61]; [62].

This study did not find any G. brevipalpis though it was previously reported. A study by Mihok [21] found $2.2 \%$ in a total fly catch of 312,801 tsetse flies. As stated above, this work was undertaken few kilometres away and did not include Akagera NP. Another monitoring work done in 2013 by Oloo "unpublished report" in Akagera NP found only one female G. brevipalpis in one site of the swamp ecosystem where traps were deployed in this study. It is a forest type species, frequently associated with waterside evergreen thickets, and forest islands in savannah habitat. The host preferences are mostly the hippo and the bush pig [63]. This indicates that its conducive habitat in the Akagera region could be the lakeshore swampy forests of the park where it was not seen during the survey. The species has both poor response to traps and odour bait attractants. However, G. brevipalpis is in most cases found in few numbers when co-existing with the Morsitans (savannah) group [64]. There is a need to investigate whether the morsitans species hamper the survival and the distribution of this species, especially when it has a conducive environment or it has simply disappeared from the area.

The absence of tsetse flies in a trap catch does not necessarily mean their absence in the area [65];[9]. Many factors are involved and the behaviour of some species differ in response to the trapping strategy. There is need for regular monitoring by using different methodologies to better understand the behaviour of tsetse populations of the area. In particular, G. morsitans responds well to the visual moving objects compared to G. pallidipes which is attracted to stationary baits [66]; [67].

\section{Conclusion And Potential Implications}

Both G. pallidipes and G. morsitans are vectors of trypanosome infections to livestock and humans. From this study, G. pallidipes could be the more important vector due to its higher density. Tsetse occurrence seems to be limited to the protected Akagera NP and a narrow band around it. The infestation was significantly lower in the buffer area and dropped quickly to zero at a few kilometre distance away from 
the park border in both seasons. The decline in tsetse distribution indicates the possibility of controlling the Glossina vectors, and eventually African Trypanosomosis in the area.

There are already some control strategies being implemented in the area by the national veterinary services such as the distribution of subsidised NGU traps to farmers and sensitisation on bush clearing. Farmers constantly use trypanocides to fight AAT, but rarely in a systematic way. On the park side, tourists are warned of tsetse flies and target screens are installed along the roads inside the park. Despite these efforts, there is need for a more coordinated control mechanism using a multidisciplinary approach involving all the concerned parties. We suggest a combination of vector control, community engagement and improved farming practices, as tsetse flies are limited to a known area. The vector control should focus on the spatial targeting of interventions in some areas of the park and the buffer zone around it. The study recommends the regular surveillance of both animal and human trypanosomiasis at the buffer zone even though the tsetse distribution rapidly decreases outside the park. This paper is part of a broader study; data on trypanosomes has been collected and will be presented in a separate paper.

There is a lack of data on tsetse presence in any other area of the country and there are no records in the veterinary services so far. This leads to hypothesizing that the Akagera region could be the main, and possibly the only area with a tsetse challenge in Rwanda. However, there is a need to have a national level picture of the tsetse and trypanosomosis challenge, and confirm the absence of the vector from other areas that were historically or are still potentially at risk. Given that the two adjacent game reserves in Tanzania are infested and tsetse flies are dynamic and conducive environment-dependent, we recommend regionally coordinated control efforts and regular monitoring in the predictive areas to keep the distribution updated.

The outcomes of this study provide a baseline for the determination of the most appropriate method of tsetse population reduction or elimination. These findings are also expected to contribute to the development of a national atlas of tsetse and AAT, and to inform the Progressive Control Pathway (PCP) to reduce or eliminate the burden of AAT. In the same way, the findings are a contribution to Rwanda's dossier for WHO validation of the elimination of rhodesiense sleeping sickness as a public health problem.

\section{Abbreviations}

AAT: Animal African Trypanosomiasis; AD: Apparent Density; ANOVA: Analysis Of Variance; CGIAR : Consultative Group on International Agricultural Research; FTD: Fly per Trap per Day; G.: Glossina; GIS: Geographic Information System; HAT: Human African Trypanosomosis; IFAD: International Fund for Agricultural Development; NISR: National Institute of Statistics of Rwanda; NP: National Park; OR: Odds Ratio; PAAT: Programme Against African Trypanosomosis; PCP: Progressive Control Pathway; PATTEC: Pan African Tsetse and Trypanosomosis Eradication Campaign; RAB: Rwanda Agriculture and Animal Resources development Board; REMA: Rwanda Environment Management Authority; SPSS: Statistical 
Product and Service Solutions; UNFAO: Food and Agriculture Organization of the United Nations; WHO : World Health Organisation.

\section{Declarations}

\section{Ethics approval and consent to participate}

Not applicable.

\section{Consent for publication}

Not applicable.

\section{Availability of data and material}

The data sets supporting the conclusions of this article are included within the article and its additional files.

\section{Competing interests}

The authors declare that they have no competing interests.

\section{Funding}

- This study was supported by the United States Agency for International Development, as part of the Feed the Future initiative, under the CGIAR Fund, award number BFS G-11-00002, and the predecessor fund the Food Security and Crisis Mitigation II grant, award number EEM-G-00-04-00013. The funder supported the data collection phase I of this work. The views expressed herein do not necessarily reflect the official opinion of the donors.

- Rwanda Dairy Development Project, funded by the International Fund for Agricultural Development (IFAD) - project ID: 2000001195 through Rwanda Agriculture and Animal Resources Board for field support (phase II data collection) and laboratory facilities. The views expressed herein do not necessarily reflect the official opinion of the donors.

\section{Authors' contributions}

RGS: project design \& Conceptualization, Investigation, data collection and identification, original draft preparation; MGN: Data collection, identification, original draft preparation; $\mathrm{RH}$ : analysed and interpreted data; GC, MP, WZ: Writing-review \& editing and GIS expertise; SMG, NM, DKM and JG: project design, supervision, review and editing.

All authors read and approved the final version of the manuscript.

\section{Acknowledgements}


- We are thankful to the administration of Kayonza, Gatsibo, and Nyagatare districts for the permission to conduct the fieldwork;

- African Parks through Akagera National Park management and Rwanda Development Board for the research permission. African Parks manages Akagera National Park; a non-profit conservation organisation that manages protected areas on behalf of governments across Africa, through a public-private partnership with the Rwanda Development Board;

- The ethics committees of the Faculty of Veterinary Medicine - University of Nairobi (REF: FVM BAUEC/2019/246) and the College of Agriculture and Veterinary Medicine - University of Rwanda (REF:030/19/DRI) for the research ethical approval ;

\section{Collaboration}

- The International Centre for Insect Physiology and Ecology (icipe) for the provision of the biconical traps used throughout the study;

- The Rwanda Agriculture and Animal Resources Development Board (RAB) and the School of Veterinary Medicine, the University of Rwanda for laboratory facilities;

- The Animal Production and Health Division of the Food and Agriculture Organization of the United Nations (FAO), in the framework of the Programme Against African Trypanosomosis (PAAT), for the guidance and GIS expertise;

- Last but not least, Dr. Isidore Gafarasi, Dr. Claire d'Andre Hirwa, Mr. J. Claude Mpayimana, and Mr. Ernest Munyagishali; Animal Resources Officers at district and sector level, students and farmers for field facilitation, data collection and analysis.

\section{Disclaimers}

The boundaries and names shown and the designations used on the maps presented in this paper do not imply the expression of any opinion whatsoever on the part of FAO concerning the legal status of any country, territory, city or area or of its authorities, or concerning the delimitation of its frontiers or boundaries. Dotted lines on maps represent approximate borderlines for which there may not yet be full agreement. The views expressed in this paper are those of the authors and do not necessarily reflect the views of FAO.

\section{References}

[1] Jordan AM. Tsetse flies as vectors of trypanosomes. Vet Parasitol 1976;2:143-52.

[2] Maudlin I, Holmes P, Miles M. The Trypanosomes. Wallington, UK: CABI Publishing; 2004.

[3] Büscher P, Cecchi G, Jamonneau V, Priotto G. Human African trypanosomiasis. Lancet 2017;390:2397-409. https://doi.org/10.1016/S0140-6736(17)31510-6. 
[4] Cayla M, Rojas F, Silvester E, Venter F, Matthews KR. African trypanosomes. Parasit Vectors 2019;12:190. https://doi.org/10.1186/s13071-019-3355-5.

[5] Dicko AH, Percoma L, Sow A, Adam Y, Mahama C, Sidibé l, et al. A spatio-temporal model of African animal trypanosomosis risk. PLoS Negl Trop Dis 2015;9:1-20.

https://doi.org/10.1371/journal.pntd.0003921.

[6] Ngonyoka A, Gwakisa PS, Estes AB, Salekwa LP, Nnko HJ, Hudson PJ, et al. Patterns of tsetse abundance and trypanosome infection rates among habitats of surveyed villages in Maasai steppe of northern Tanzania. Infect Dis Poverty 2017;6:126. https://doi.org/10.1186/s40249-017-0340-0.

[7] Diall O, Cecchi G, Wanda G, Argilés-Herrero R, Vreysen MJB, Cattoli G, et al. Developing a Progressive Control Pathway for African Animal Trypanosomosis. Trends Parasitol 2017;33:499-509. https://doi.org/10.1016/j.pt.2017.02.005.

[8] Shaw A, Wint W, Cecchi G, Torr S, Waiswa C, Alemu, Temesgen Eregae M, et al. Intervening against bovine trypanosomosis in eastern Africa: mapping the costs and benefits. 2017.

[9] Chikowore G, Dicko AH, Chinwada P, Zimba M, Shereni W, Roger F, et al. A pilot study to delimit tsetse target populations in Zimbabwe. PLoS Negl Trop Dis 2017;11:e0005566.

https://doi.org/10.1371/journal.pntd.0005566.

[10] Cecchi G, Mattioli RC, Slingenbergh J, De la Rocque S. Land cover and tsetse fly distributions in subSaharan Africa. Med Vet Entomol 2008;22:364-73. https://doi.org/10.1111/j.1365-2915.2008.00747.x.

[11] Munang'andu HM, Siamudaala V, Munyeme M, Nalubamba KS. A Review of Ecological Factors Associated with the Epidemiology of Wildlife Trypanosomiasis in the Luangwa and Zambezi Valley Ecosystems of Zambia. Interdiscip Perspect Infect Dis 2012;2012:1-13.

https://doi.org/10.1155/2012/372523.

[12] Van den Bossche P, Rocque S de La, Hendrickx G, Bouyer J. A changing environment and the epidemiology of tsetse-transmitted livestock trypanosomiasis. Trends Parasitol 2010;26:236-43. https://doi.org/10.1016/j.pt.2010.02.010.

[13] Ducheyne E, Mweempwa C, De Pus C, Vernieuwe H, De Deken R, Hendrickx G, et al. The impact of habitat fragmentation on tsetse abundance on the plateau of eastern Zambia. Prev Vet Med 2009;91:118. https://doi.org/10.1016/j.prevetmed.2009.05.009.

[14] Lord JS, Torr SJ, Auty HK, Brock PM, Byamungu M, Hargrove JW, et al. Geostatistical models using remotely-sensed data predict savanna tsetse decline across the interface between protected and unprotected areas in Serengeti, Tanzania. J Appl Ecol 2018;55:1997-2007.

https://doi.org/10.1111/1365-2664.13091. 
[15] de Gier J, Cecchi G, Paone M, Dede P, Zhao W. The continental atlas of tsetse and African animal trypanosomosis in Nigeria. Acta Trop 2020;204:105328.

https://doi.org/10.1016/j.actatropica.2020.105328.

[16] Henrard GL. Répartition des glossines au Congo belge et au Ruanda- Urundi. Bull Inst Roy Col Belge 1951 ,tome XXI.

[17] Evens F. Dispersion géograpliique des glossines au Congo belge. Mémoires l'Institut R Des Sci Nat Belgique 1953;2" série,:1-70.

[18] Benoit PLG. Contribution à l'étude de la faune entomologique du Ruanda-Urundi (Mission Basilewsky 1953). Ann Du Musée R Du Congo Belge à Tervuren 1955,tome 40:357-358.

[19] Berghe $L$ van den, Lambrecht FL. Étude biologique et écologique des glossines dans la région du Mutara (Ruanda). Mem Acad R Belg Cl Sci 8 1956;4:1-101.

[20] F.Evens, M.Meyus LP and CN. Dispersion g é o g r a $\mathrm{p} \mathrm{h}$ i q u e des GLOSSINES au Congo belge et au Ruanda-Urundi 1957.

[21] Mihok S, Otieno LH, Tarimo CS. Trypanosome infection rates in tsetse flies (Diptera: Glossinidae) and cattle during tsetse control operations in the Kagera River region of Rwanda. Bull Entomol Res 1992;82:361-7. https://doi.org/10.1017/S0007485300041158.

[22] Moloo SK. Distribution of Glossina species in Africa. Acta Trop 1985;42:275-81.

[23] Katondo KM. Revision of second edition of tsetse distribution maps. An interim report. Int J Trop Insect Sci 1984;5:381-8. https://doi.org/10.1017/s1742758400008705.

[24] J.Ford KMK. Maps of tsetse flies (Glossina) distribution in Africa, 1973 according to sub-generic groups on scale of 1:5 000 000. Bull Anim Heal Prod Afr 1977;25:187-93.

[25] Moloo SK. The distribution of Glossina species in Africa and their natural hosts. Int J Trop Insect Sci 1993;14:511-27. https://doi.org/10.1017/S1742758400014211.

[26] NISR. Seasonal agricultural survey 2020 - Season B report. 2020.

[27] Hajabakiga P. Land conflict: addressing land issues in post conflict setting: the case of Rwanda. L. AFRICA Mark. asset or Secur. livelihood?, 2004, p. 45-52.

[28] Sun P, Bariyanga JD, Wronski T. A literature review of mammalian research respective to the Akagera ecosystem in Rwanda. Rwanda J 2018;2. https://doi.org/10.4314/rj.v2i1.1d.

[29] Apio A, Plath M, Wronski T. Recovery of Ungulate Populations in Post-Civil War Akagera National Park, Rwanda. J East African Nat Hist 2015;104:127-41. https://doi.org/10.2982/028.104.0110. 
[30] Macpherson DDB. Report on an Aerial Wildlife Census of Akagera National Park, Rwanda. 2019.

[31] Udahemuka JC, Aboge GO, Obiero GO, Lebea PJ, Onono JO, Paone M. Risk factors for the incursion, spread and persistence of the foot and mouth disease virus in Eastern Rwanda. BMC Vet Res 2020;16:387. https://doi.org/10.1186/s12917-020-02610-1.

[32] Ntivuguruzwa JB, Kolo FB, Gashururu RS, Umurerwa L, Byaruhanga C, van Heerden $\mathrm{H}$. Seroprevalence and Associated Risk Factors of Bovine Brucellosis at the Wildlife-Livestock-Human Interface in Rwanda. Microorganisms 2020;8:1553. https://doi.org/10.3390/microorganisms8101553.

[33] Stanton MC, Esterhuizen J, Tirados I, Betts H, Torr SJ. The development of high resolution maps of tsetse abundance to guide interventions against human African trypanosomiasis in northern Uganda. Parasit Vectors 2018;11:340. https://doi.org/10.1186/s13071-018-2922-5.

[34] R Franco, Cecchi G, Priotto G, Paone M, Diarra A, Grout L, et al. Monitoring the elimination of human African trypanosomiasis at continental and country level: Update to 2018. PLoS Negl Trop Dis 2020:118. https://doi.org/10.1371/journal.pntd.0008261.

[35] REMA. Atlas of Rwanda's changing environment, implications for climate change resilience. 2011.

[36] Viljoen P. Akagera National Park, Rwanda, Aerial Wildlife Survey, August 2010. 2010.

[37] Macpherson D. Report on an Aerial Census of Akagera National Park, Rwanda. 2013.

[38] Leak S, Ejigu D, Vreysen M. Collection of Entomological Baseline Data for Tsetse Area-Wide Integrated Pest Management Programmes. 2008.

[39] Challier A LC. A new trap for capturing Glossina flies (Diptera: Muscidae), description and field trials. Cah ORSTOM Entomol Med Parasitol 1973;11:251-62.:251-62.

[40] Challier A., Eyraud M. LA et LC. Amélioration du rendement du piège biconique pour glossines ( Diptera , Glossinidae ) par I ' emploi d ' un cône inférieur bleu 1977;XV:283-6.

[41] Nnko HJ, Ngonyoka A, Salekwa L, Estes AB, Hudson PJ, Gwakisa PS, et al. Seasonal variation of tsetse fly species abundance and prevalence of trypanosomes in the Maasai Steppe, Tanzania. J Vector Ecol 2017;42:24-33. https://doi.org/10.1111/jvec.12236.

[42] Mulandane FC, Snyman LP, Brito DRA, Bouyer J, Fafetine J, Van Den Abbeele J, et al. Evaluation of the relative roles of the Tabanidae and Glossinidae in the transmission of trypanosomosis in drug resistance hotspots in Mozambique. Parasites and Vectors 2020;13. https://doi.org/10.1186/s13071020-04087-1.

[43] Pollock JN. Training Manual for Tsetse control personnel - Tsetse biology, systematics and distribution; techniques. vol. 1. 1982. 
[44] Wittemyer G, Elsen P, Bean WT, Burton ACO, Brashares JS. Accelerated Human Population Growth at Protected Area Edges. Science (80- ) 2008;321:123-6. https://doi.org/10.1126/science.1158900.

[45] Mweempwa C, Marcotty T, De Pus C, Penzhorn BL, Dicko AH, Bouyer J, et al. Impact of habitat fragmentation on tsetse populations and trypanosomosis risk in Eastern Zambia. Parasit Vectors 2015;8:406. https://doi.org/10.1186/s13071-015-1018-8.

[46] Gondwe N, Marcotty T, Vanwambeke SO, De Pus C, Mulumba M, Van den Bossche P. Distribution and Density of Tsetse Flies (Glossinidae: Diptera) at the Game/People/Livestock Interface of the Nkhotakota Game Reserve Human Sleeping Sickness Focus in Malawi. Ecohealth 2009;6:260-5. https://doi.org/10.1007/s10393-009-0252-y.

[47] Diarra B, Diarra M, Diall O, Bass B, Sanogo Y, Coulibaly E, et al. A national atlas of tsetse and African animal trypanosomosis in Mali. Parasit Vectors 2019;12:466. https://doi.org/10.1186/s13071-019-37213.

[48] Daffa J, Byamungu M, Nsengwa G, Mwambembe E, Mleche W. Tsetse distribution in Tanzania: 2012 status. Spec Issue 2013;28:1-11.

[49] Abila PP, Slotman MA, Parmakelis A, Dion KB, Robinson AS, Muwanika VB, et al. High levels of genetic differentiation between Ugandan Glossina fuscipes fuscipes populations separated by Lake Kyoga. PLoS Negl Trop Dis 2008;2. https://doi.org/10.1371/journal.pntd.0000242.

[50] Ciosi M, Masiga DK, Turner CMR. Laboratory Colonisation and Genetic Bottlenecks in the Tsetse Fly Glossina pallidipes. PLoS Negl Trop Dis 2014;8. https://doi.org/10.1371/journal.pntd.0002697.

[51] Saarman NP, Opiro R, Hyseni C, Echodu R, Opiyo EA, Dion K, et al. The population genomics of multiple tsetse fly ( Glossina fuscipes fuscipes ) admixture zones in Uganda. Mol Ecol 2019;28:66-85. https://doi.org/10.1111/mec.14957.

[52] Ngari NN, Gamba DO, Olet PA, Zhao W, Paone M, Cecchi G. Developing a national atlas to support the progressive control of tsetse-transmitted animal trypanosomosis in Kenya. Parasit Vectors 2020;13:286. https://doi.org/10.1186/s13071-020-04156-5.

[53] Salekwa LP, Nnko HJ, Ngonyoka A, Estes AB, Agaba M, Gwakisa PS. Relative abundance of tsetse fly species and their infection rates in simanjiro, Northern Tanzania. Livest Res Rural Dev 2014;26:1-8.

[54] Camberlin P, Wairoto JG. Intraseasonal wind anomalies related to wet and dry spells during the "long" and "short" rainy seasons in Kenya. Theor Appl Climatol 1997;58:57-69. https://doi.org/10.1007/BF00867432.

[55] Shereni W, Anderson NE, Nyakupinda L, Cecchi G. Spatial distribution and trypanosome infection of tsetse flies in the sleeping sickness focus of Zimbabwe in Hurungwe District. Parasit Vectors 2016;9:605. https://doi.org/10.1186/s13071-016-1879-5. 
[56] Bateta R, Saarman NP, Okeyo WA, Dion K, Johnson T, Mireji PO, et al. Phylogeography and population structure of the tsetse fly Glossina pallidipes in Kenya and the Serengeti ecosystem. PLoS Negl Trop Dis 2020;14:e0007855. https://doi.org/10.1371/journal.pntd.0007855.

[57] Okeyo WA, Saarman NP, Mengual M, Dion K, Bateta R, Mireji PO, et al. Temporal genetic differentiation in Glossina pallidipes tsetse fly populations in Kenya. Parasit Vectors 2017;10:471. https://doi.org/10.1186/s13071-017-2415-y.

[58] Moore N, Messina J. A landscape and climate data logistic model of tsetse distribution in Kenya. PLoS One 2010;5:e11809. https://doi.org/10.1371/journal.pone.0011809.

[59] Malele II, Magwisha HB, Nyingilili HS, Mamiro KA, Rukambile EJ, Daffa JW, et al. Multiple Trypanosoma infections are common amongst Glossina species in the new farming areas of Rufiji district, Tanzania. Parasit Vectors 2011;4:217. https://doi.org/10.1186/1756-3305-4-217.

[60] Wamwiri FN, Changasi RE. Tsetse Flies (Glossina) as Vectors of Human African Trypanosomiasis: A Review. Biomed Res Int 2016;2016:6201350. https://doi.org/10.1155/2016/6201350.

[61] Adam Y, Bouyer J, Dayo G, Mahama Cl, Vreysen MJB, Cecchi G, et al. Genetic comparison of Glossina tachinoides populations in three river basins of the Upper West Region of Ghana and implications for tsetse control. Infect Genet Evol 2014. https://doi.org/10.1016/j.meegid.2014.03.023.

[62] Bouyer, Jérémy et al. Mapping landscape friction to locate isolated tsetse populations that are candidates for elimination 2015;112:14575-80. https://doi.org/10.1073/pnas.1516778112.

[63] Pollock JN. Training Manual for Tsetse control personnel - Ecology and behaviour of tsetse. vol. 2. Rome: FAO; 1982.

[64] Auty H, Anderson NE, Picozzi K, Lembo T, Mubanga J, Hoare R, et al. Trypanosome Diversity in Wildlife Species from the Serengeti and Luangwa Valley Ecosystems. PLoS Negl Trop Dis 2012;6:e1828. https://doi.org/10.1371/journal.pntd.0001828.

[65] Bouyer J, Seck MT, Sall B, Ndiaye EY, Guerrini L, Vreysen MJB. Stratified Entomological Sampling in Preparation for an Area-Wide Integrated Pest Management Program: The Example of Glossina palpalis gambiensis (Diptera: Glossinidae) in the Niayes of Senegal. J Med Entomol 2010;47:543-52. https://doi.org/10.1603/ME09149.

[66] Vale GA. The responses of tsetse flies (Diptera, Glossinidae) to mobile and stationary baits. Bull Entomol Res 1974;64:545-88. https://doi.org/10.1017/S0007485300035860.

[67] Vale GA. Responses of tsetse flies ( Diptera: Glossinidae ) to vegetation in Zimbabwe: implications for population distribution and bait siting Chapter 1 : Introduction, 1998. 

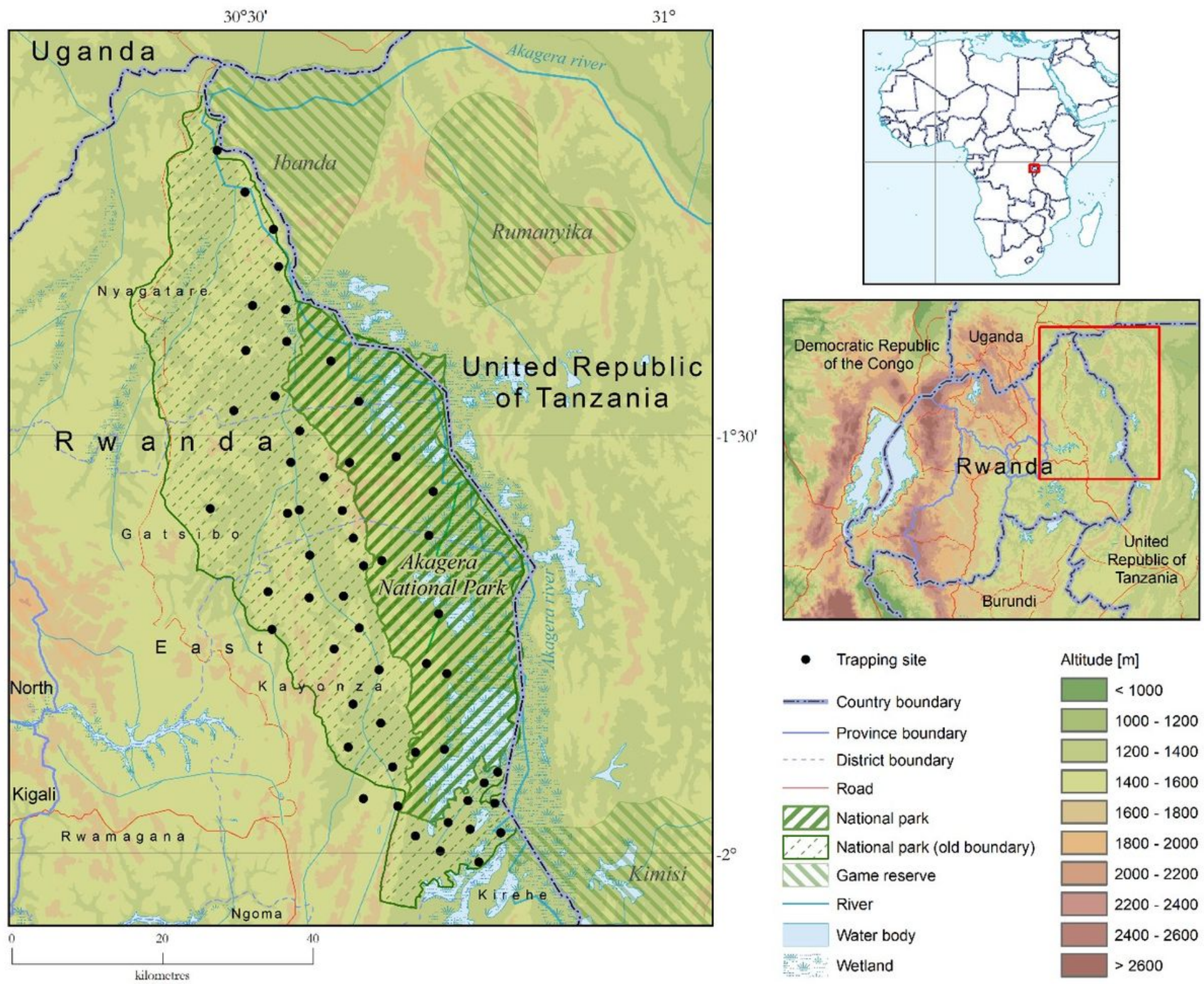

\section{Figure 1}

Study area with the old park boundaries. Note: The designations employed and the presentation of the material on this map do not imply the expression of any opinion whatsoever on the part of Research Square concerning the legal status of any country, territory, city or area or of its authorities, or concerning the delimitation of its frontiers or boundaries. This map has been provided by the authors. 


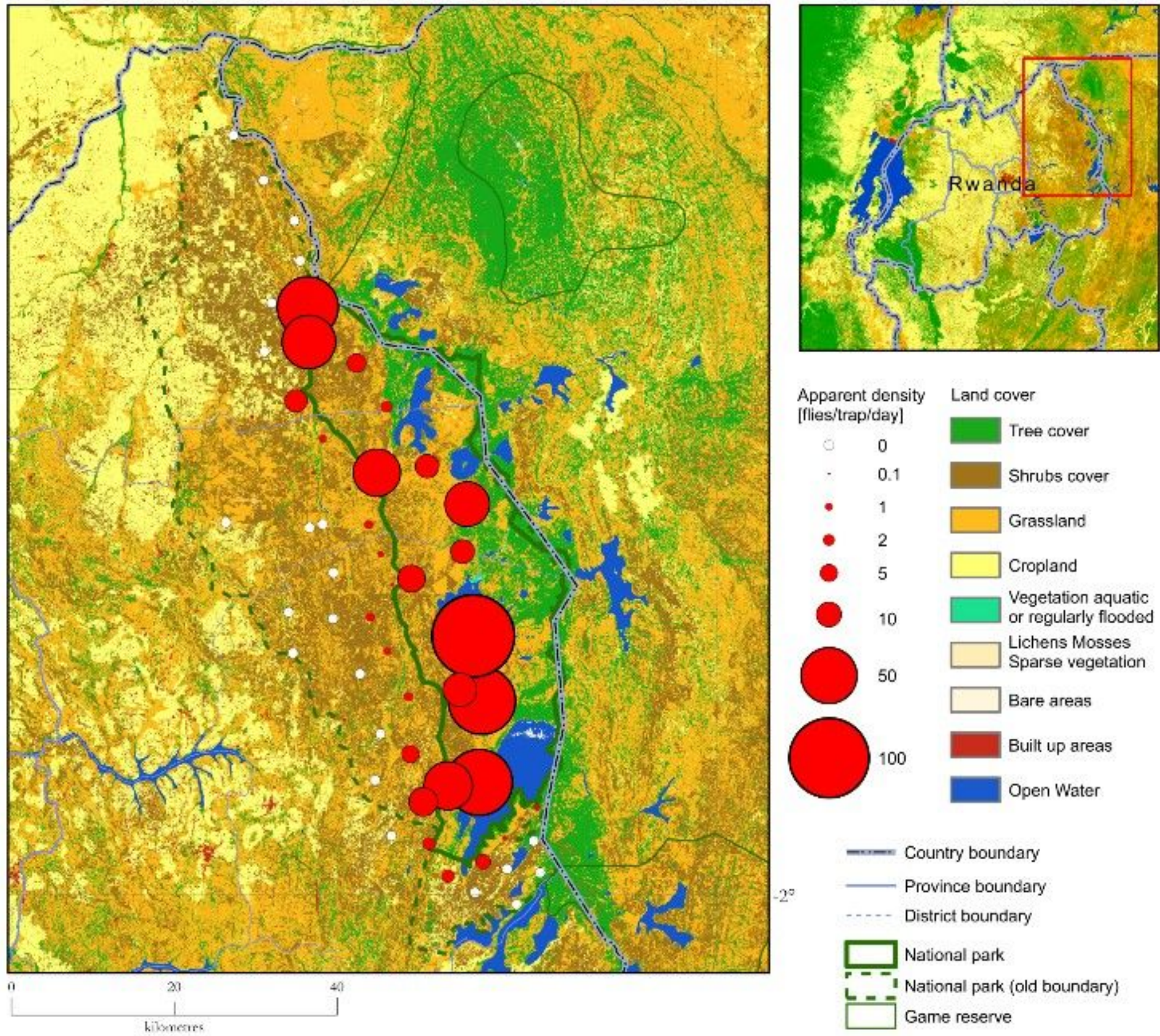

Figure 2

Apparent density with land cover (all seasons and species combined) High catches were mainly found inside the park and a narrow band of Nyagatare District. High tsetse densities are associated with swampy vegetation. Note: The designations employed and the presentation of the material on this map do not imply the expression of any opinion whatsoever on the part of Research Square concerning the legal status of any country, territory, city or area or of its authorities, or concerning the delimitation of its frontiers or boundaries. This map has been provided by the authors. 
Glossina pallidipes

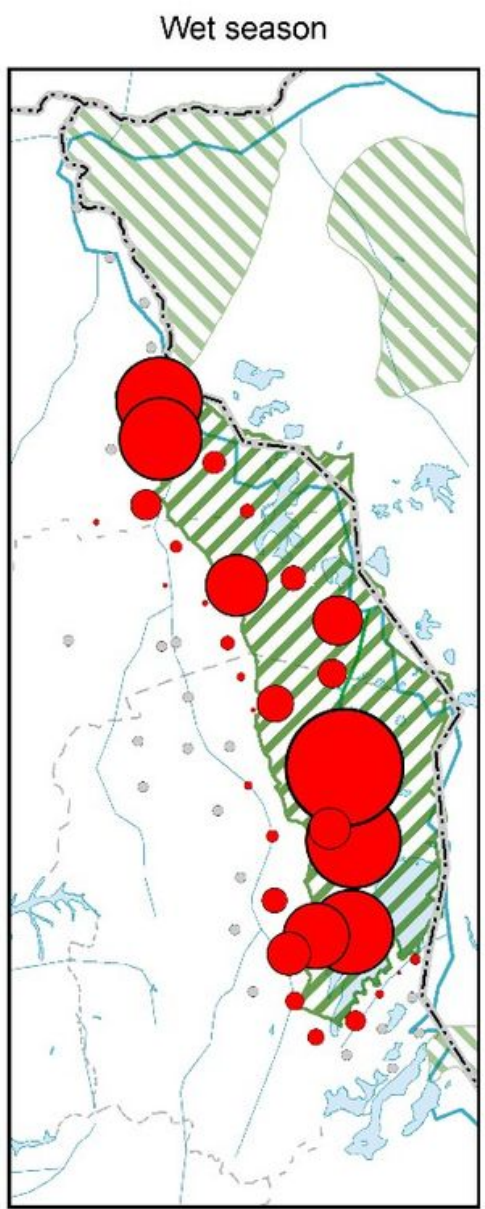

Apparent density [flies/trap/day]

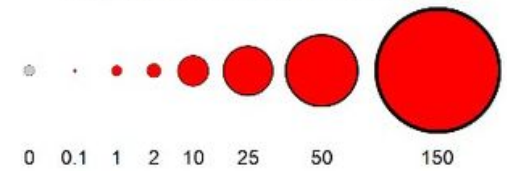

Glossina morsitans centralis

Wet season

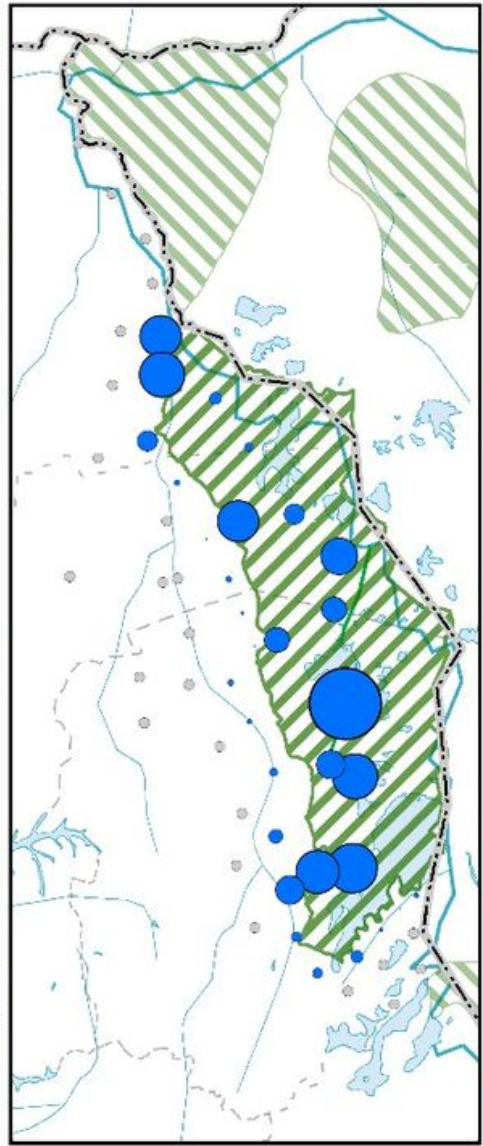

Dry season

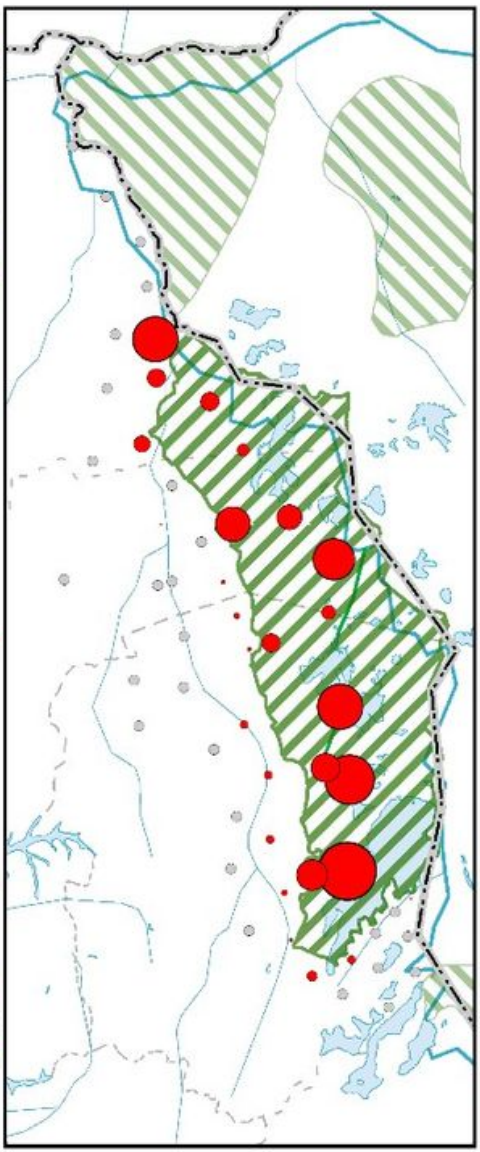

Apparent density [flies/trap/day]

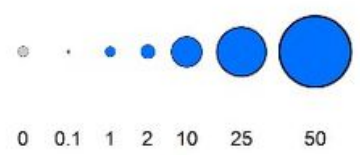

Figure 3

Seasonal occurrence of G. pallidipes and G. morsitans centralis in and around Akagera National Park. 

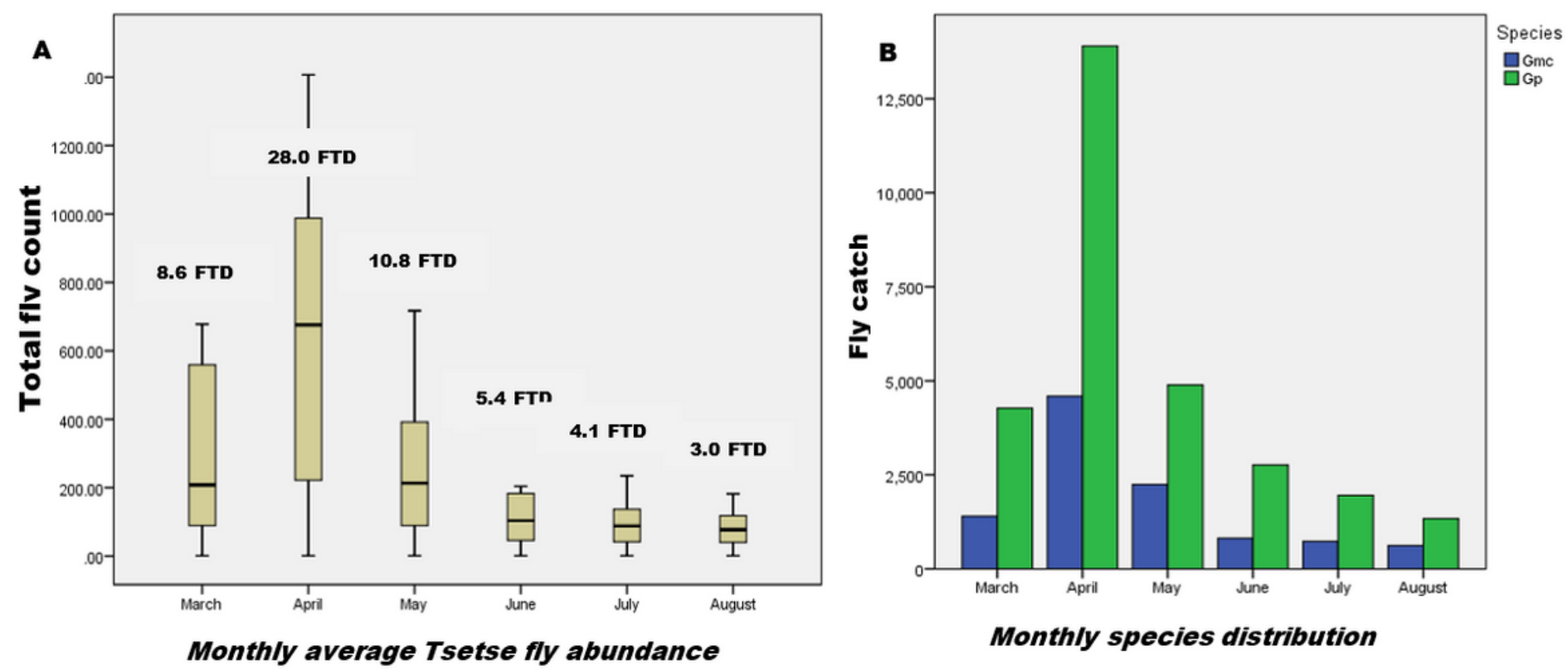

Figure 4

Monthly fly abundance (A) and species composition (B) The difference is highly significant in April $(p=0.00,95 \% \mathrm{Cl})$ compared to other months. $\mathrm{Gmc}=$ Glossina morsitans centralis; $\mathrm{Gp}=$ Glossina pallidipes; FTD= Fly per Trap per Day 

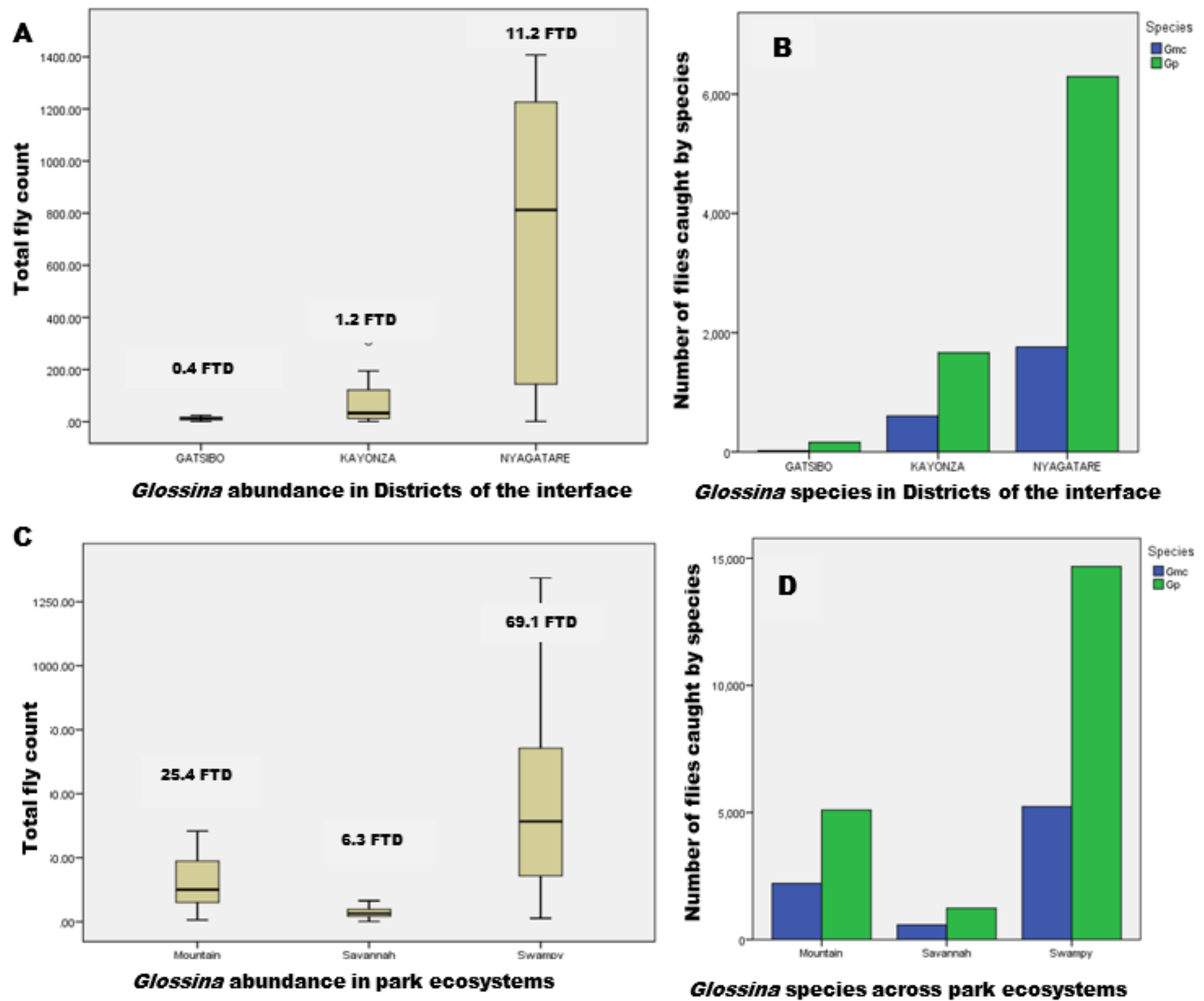

\section{Figure 5}

The abundance and distribution of Glossina within the study strata Districts are strata at the interface (A, B) and ecosystems of Akagera NP (C, D). Gmc = Glossina morsitans centralis; Gp= Glossina pallidipes; FTD=Fly per Trap per Day. 


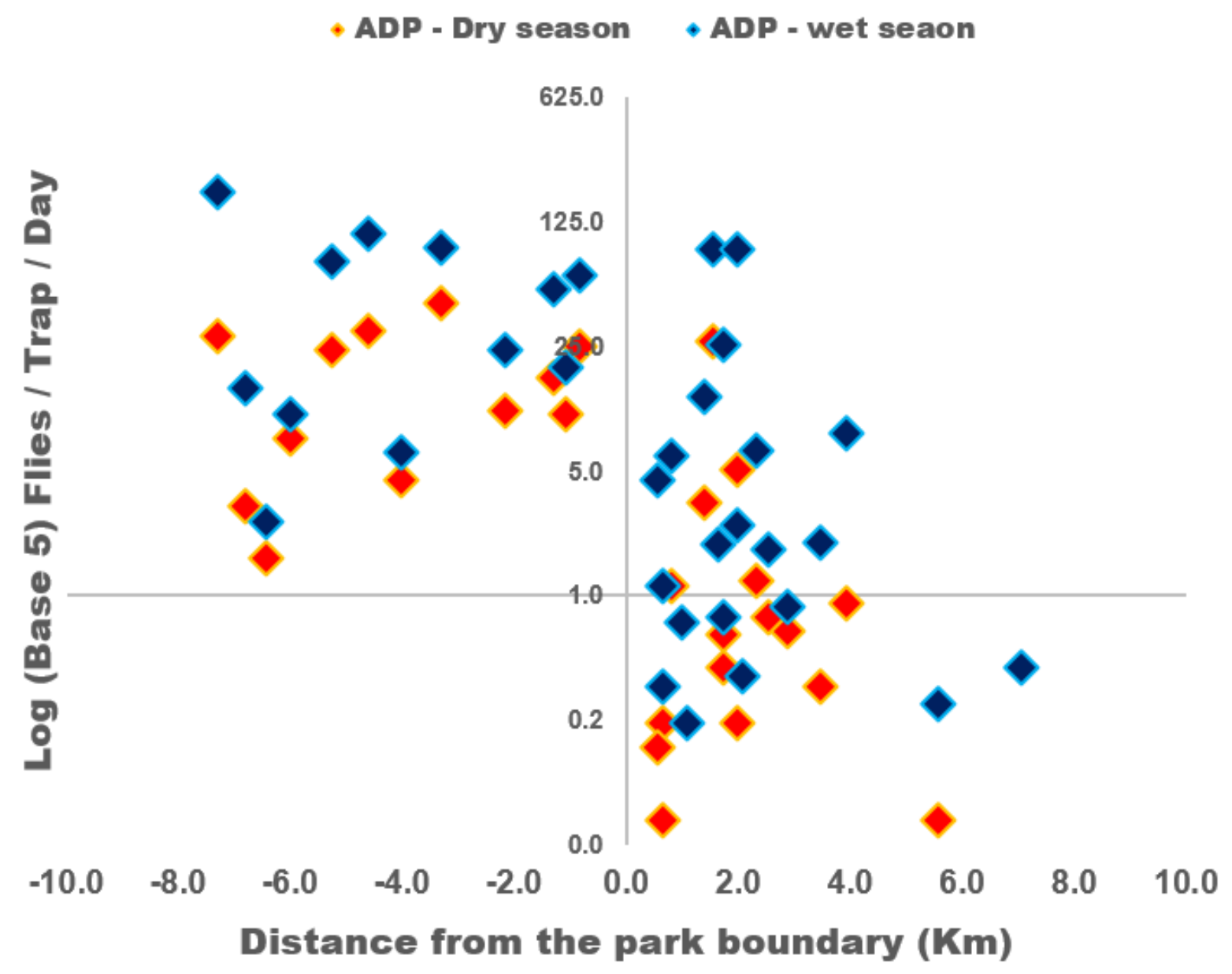

Figure 6

Tsetse density with reference to the distance from the park boundary Negative distance values signpost the sites inside Akagera park, whereas positive values show the sites at the interface area. The further tsetse fly was captured in $7 \mathrm{Km}$ from the park boundary during the wet season.

\section{Supplementary Files}

This is a list of supplementary files associated with this preprint. Click to download.

- Detaileddatasetforentomologicalsurvey.xlsx

- Graphicalabstract.jpg

- Summarizeddatasetforseasonalvariationmaps.xlsx 